\title{
THE DEVELOPMENT STRATEGY OF NAVY BASE AS A CARRIER IN THE ORDER OF IMPROVING THE STATE DEFENSE AT SEA
}

\author{
Zulkifli Muhammad, Fadli Mohammad, Nurjanah \\ University of Brawijaya, Malang, Indonesia \\ *E-mail: zulkifli@student.ub.ac.id
}

\begin{abstract}
Indonesia is the $7^{\text {th }}$ largest country in the world with a very strategic location between the continents of Asia and the continents of Australia and the Pacific Ocean and the Indian Ocean. This condition provides an advantage as well as a vulnerability to the sovereignty of the Indonesian state. This has an impact on the task of the Indonesian Navy (TNI AL) in maintaining state sovereignty and enforcing the law in Indonesia's jurisdictional seas. In carrying out this task, the Indonesian Navy is experiencing obstacles because the vast field of work and potential threats to state sovereignty that exist today are not comparable to the conditions of the Main Weapon System Equipment (Alutsista) owned, so it is necessary to develop a Navy Base that can function as a carrier for strong national defense. Writing this article aims to determine the right strategy by analyzing the strengths and weaknesses of the Indonesian Navy in the face of existing opportunities and threats. From this analysis, a strategy can be determined to develop the Indonesian Navy Base as an aircraft carrier. Of the four strategies produced, the best strategy to implement is to develop the Indonesian Navy Base as an aircraft carrier with the support of the central government and local governments as well as high-ranking of Indonesian armed force/Indonesian Navy officials to realize state defense policies and the mandate of the law to improve national defense to maintain national security, territory and sovereignty of the Republic of Indonesia.
\end{abstract}

\section{KEY WORDS}

Strategy, Indonesian naval base, aircraft carrier.

Indonesia is one of the largest countries in the world because it has an area of land and sea reaching $5,193,250 \mathrm{~km}^{2}$. With this area, Indonesia is the 7th largest country in the world after Russia, Canada, the United States, China, Brazil and Australia. Indonesia is the 2nd largest country when compared to the area of countries in Asia and is the largest country when compared to other Southeast Asian countries. ${ }^{1}$ In addition, Indonesia is also the largest archipelagic country in the world with a very wide maritime area. ${ }^{2}$ The number of islands owned by Indonesia is 17,504 islands and as many as 16,056 islands of which have been recognized by the United Nations. ${ }^{3}$

The State of Indonesia has also received international recognition as an archipelagic country through the United Nations Convention on the Law of The Sea (UNCLOS) in 1982. Then the Indonesian government ratified the ratification of UNCLOS with Law Number 17 of 1985. ${ }^{4}$ Thus, the inter-island sea area becomes an inseparable part of the Unitary State of the Republic of Indonesia (NKRI).

Geographically, Indonesia is very strategically located in a cross-world position, which is located between two continents (Asia and Australia) and two oceans (Pacific Ocean and Indian Ocean), ${ }^{5}$ making Indonesia a sea line of communication (SLOC). ) and sea trade routes (Sea Lines of Trade / SLOT) for the international world. ${ }^{6}$ This is very beneficial but at the same time it can also result in threats to the sovereignty of the Republic of Indonesia such as violations of the territory of the state's sovereignty, theft of marine resources, smuggling of goods, people smuggling, piracy, wiretapping and sabotage carried out by various parties with interests. Sir Walter Raleigh and Alfred Thayer Mahan have explained the importance of mastery of the sea, that is, whoever controls the sea will control the world's trade routes, and then he can control the world power so that eventually he can control the world. ${ }^{7}$ 
Based on the 1945 Constitution of the Republic of Indonesia (UUD 1945) in the Preamble to the fourth paragraph, it is stated that the Government of the Republic of Indonesia has an obligation to protect the entire Indonesian nation and the entire homeland of Indonesia and to promote public welfare, educate the nation's life, and participate in carrying out order. a world based on freedom, lasting peace and social justice. ${ }^{8}$ In order for these obligations to be carried out properly, the Government needs the strength of the armed forces, in this case the Indonesian National Army (TNI) where the Navy is one of the dimensions.

The strength of the Indonesian Navy is influenced by several components, such as the strength structure, technological sophistication, the level of readiness and operational sustainability of the defense equipment owned. ${ }^{9}$ Military infrastructure is a necessity that cannot be separated from national security, therefore the construction of various facilities for the needs of the Navy continues to be developed. Such as securing border areas and leading islands which will function as aircraft carriers to increase national defense at sea.

The President of the Republic of Indonesia, Joko Widodo, in his State of the Union address in Naypyidaw, Myanmar on November 13, 2014 at the 9th East Asian Summit, conveyed the Vision of the World Maritime Axis. Based on Presidential Regulation Number 16 of 2017 concerning Indonesian Maritime Policy, article 1 states that the World Maritime Axis is a vision of Indonesia to become a maritime country that is sovereign, advanced, independent, strong and able to make a positive contribution to regional and world security and peace in accordance with with the national interest. ${ }^{10}$

While watching the XXXIV Armada Jaya Exercise in 2016, the President also said that the TNI would soon have three new aircraft carriers but not the original carriers, but by turning the three outer islands of Indonesia into military bases to safeguard the sovereignty of the Republic of Indonesia. ${ }^{11}$ General TNI Gatot Nurmantyo while serving as the TNI Commander revealed that in the future the TNI paradigm could change and be perfected. The TNI's strength and capability need to be continuously improved to match the priority threats that will occur in the future. One of them is by utilizing islands of strategic value as bases or having functions such as aircraft carriers. ${ }^{12}$ Admiral Ade Supandi when he served as Chief of Naval Staff (KASAL) said that the government had plans to build three aircraft carriers on the outer islands of Indonesia, namely Natuna, Bitung and Selaru. ${ }^{13}$

With the size of the field of duty carried out by the Indonesian Navy and the potential threats faced by the current number of KRIs that still do not meet the Minimum Essential Force (MEF) standard, it is necessary to develop a defense system for the Indonesian Navy Base as an aircraft carrier in order to improve national defense at sea.

Based on the foregoing, the authors conducted research on the development strategy of the Indonesian Navy Base as an aircraft carrier in order to improve national defense at sea. In determining the strategy used Strengths, Weaknesses, Opportunities and Threats Analysis (SWOT Analysis). This method is very useful for determining the strengths and opportunities of the Indonesian Navy, which is faced with the weaknesses and threats that are currently being faced by the Indonesian Navy and potential threats in the future. The formulation of the problem used is how to determine the development strategy of the Indonesian Navy Base so that it can function as an aircraft carrier in order to improve national defense at sea.

\section{METHODS OF RESEARCH}

Based on the focus and objectives of the research, the method used in this study is a qualitative-descriptive-analytical method that produces strategic concepts in the development of the Indonesian Navy Base. This method is used with the aim of determining the strategy for developing the Indonesian Navy Base as an aircraft carrier in order to improve national defense at sea using SWOT analysis.

Strategy is the science and art of using all the resources of a nation to carry out certain policies in war and peace. ${ }^{14}$ In its development, the concept of strategy continues to develop from time to time. Hamel and Prahalad said that strategy is an action that is incremental 
(always increasing) and continuously carried out based on the point of view of what is expected in the future. According to Argyris, Mintzberg, Steiner and Miner strategy is a continuous and adaptive response to external opportunities and threats as well as internal strengths and weaknesses that can affect the organization. ${ }^{15}$

A good understanding of the concept of strategy will determine the success of a strategy that is made. Strategic formulation, known as strategic planning, is the process of preparing long-term plans, so that in the process it uses an analytical process. The goal is to develop a strategy that is in accordance with the vision, mission and policies of the organization. Important activities carried out in the analysis process understand all the information contained in a case, analyzing the situation to find out what is going on, and formulating what actions must be taken to solve the problems at hand.

Strategic planning is very necessary in order to face the development of the strategic environment, both at the global, regional and national levels which are very dynamic, complex and multidimensional. This change can lead to various forms of threats, both in the form of actual threats and potential threats as follows: ${ }^{16}$

a. Actual threats are military threats, non-military threats and hybrid threats as currently developing, both from within the country and abroad. This threat has implications for state sovereignty, territorial integrity and the safety of the entire Indonesian nation. These threats include: border area violations, separatism, terrorism and radicalism, piracy and hostagetaking of Indonesian citizens, piracy, intelligence threats or espionage, cyber threats, psychological war threats, biological weapons attacks, theft of natural resources, natural disasters, disease outbreaks, smuggling and trafficking drugs, as well as the impact of the birth of the industrial revolution 4.0 and the social revolution 5.0;

b. Potential threats are threats that have not occurred at this time, but can occur at any time in certain situations and become actual threats. This threat is in the form of conventional war or open conflict due to foreign invasion, the threat of nuclear weapons, the threat of an economic crisis, the threat of a pandemic of certain diseases and the threat of foreign immigrants.

The general guidelines for managing the Indonesian state defense are prepared based on the government's vision and mission in the field of defense and policies for the implementation of Indonesian state defense in 2020-2024 in order to realize a single defense unit in order to achieve national goals. The vision is the realization of an advanced Indonesia that is sovereign, independent, and personable, based on mutual cooperation. Meanwhile, its mission is to provide protection for the entire nation and provide a sense of security to all citizens, which is carried out through a continuation program of the transformation of a modern defense system and a professional Indonesian Armed Force (TNI). ${ }^{17}$

The Indonesian Navy has 3 (three) areas of Fleet Command (Koarmada), namely Koarmada I based in Jakarta, Koarmada II based in Surabaya and Koarmada III based in Sorong, as shown in Figure $1 .^{18}$

Each Koarmada has an area consisting of several Navy bases. The base is one of the components of the Integrated Fleet Weapon System (SSAT) which is the main supporting force in maritime combat operations, especially to support the mobility of the Republic of Indonesia Warships (KRI). ${ }^{19}$

Koarmada I has five main bases for the Indonesian Navy (Lantamal), namely: Lantamal I Belawan, Lantamal |I Padang, Lantamal III Jakarta, Lantamal IV Tanjung Pinang and Lantamal XII Pontianak. Koarmada II also has five Lantamal, namely: Lantamal V Surabaya, Lantamal VI Makassar, Lantamal VII Kupang, Lantamal VIII Manado and Lantamal XIII Tarakan. Meanwhile, Koarmada III only has four Lantamal, namely: Lantamal IX Ambon, Lantamal X Jayapura, Lantamal XI Merauke and Lantamal XIV Sorong.

Based on the regional division, there are three Lantamal whose task areas include Natuna, Bitung and Selaru, namely: Lantamal IV Tanjung Pinang for Natuna, Lantamal VIII Manado for Bitung and Lantamal IX Ambon for Selaru.

Lantamal IV Tanjung Pinang oversees five Navy bases (Lanal), namely: Lanal Ranai, Lanal Batam, Lanal Tanjung Balai Karimun, Lanal Tarempa, Lanal Dabo Singkep. 


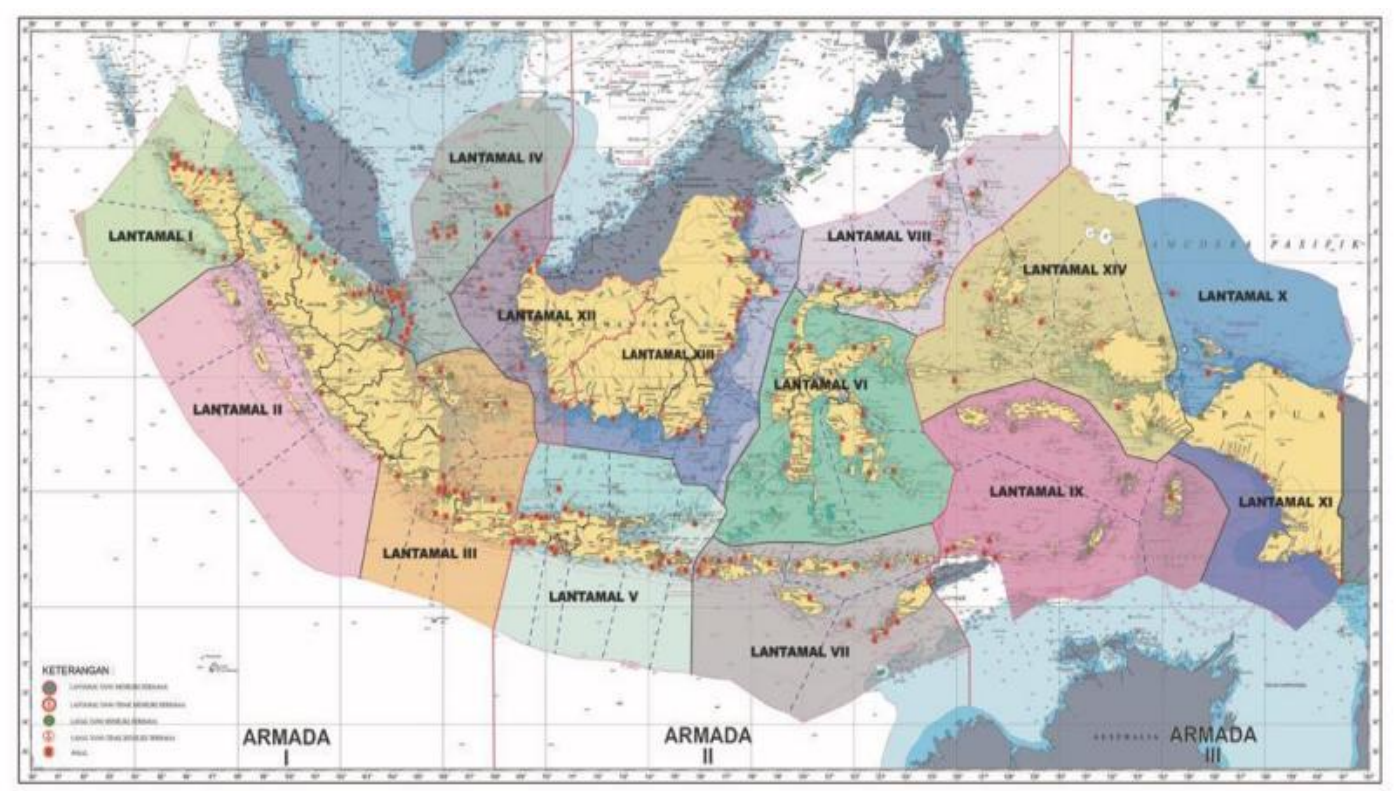

Figure 1 - Map of the Republic of Indonesia Fleet Command Work Areas I, II, III (Source: Puskondal TNI AL, 2018)

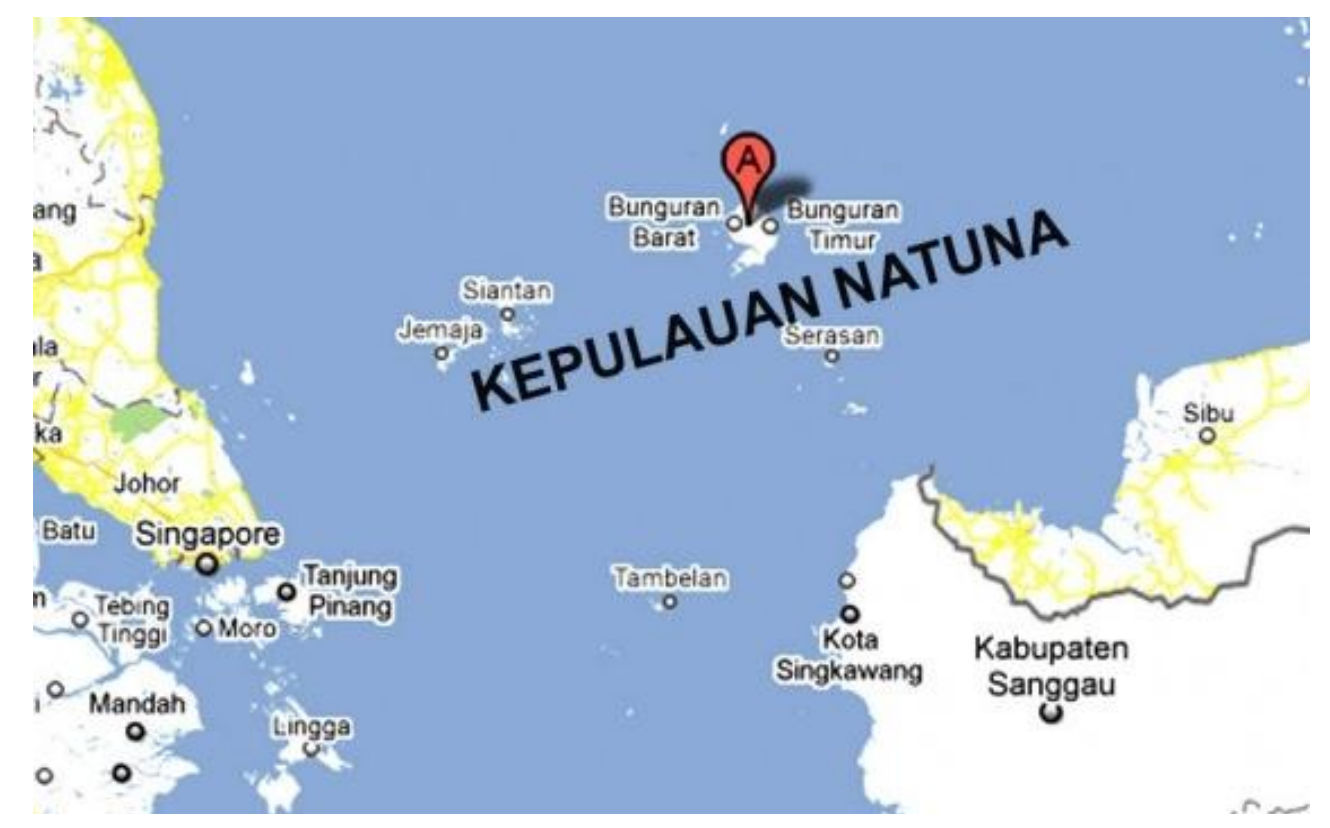

Figure 1 - Map of Natuna Area's

The most appropriate Lanal to be developed from the five Lanals is Lanal Ranai which is located in the Natuna Islands. Lanal Ranai was developed into Lantamal so that it can carry out the following functions: ${ }^{20}$

a. Operational unit support functions which include: anchor facility support function, maintenance and repair facility support function, debriefing facility support function, personnel maintenance facility support function, base support facility support function;

b. Marine safety function;

c. Matra Laut empowerment function;

d. The function of the aircraft carrier as a base specificity function.

Meanwhile, the organizational structure of the base was increased to:

a. Leadership Elements: Commander and Deputy Commander;

b. Leadership Assistant Elements: Planning and Budgeting Staff, Intelligence Staff, Operations Staff, Personnel Staff, Logistics Staff; 
c. Service Elements: Headquarters Detachment, Cash Holder, Secretariat;

d. Central Implementing Elements: Maritime Potential Service, Harbormaster Service, Legal Service, Personnel Administration Service, Health Service, Base Facilities Service, Supplies Service, Maintenance and Repair Service, Transportation Service, Information Service, Maintenance and Repair Facilities;

e. Technical Implementing Elements: Military Police, Marine Security Unit, Communications Unit, Hospital, Intelligence Team;

f. Elements under Operational Control (BKO) at the Technical Implementing Level, Marine Defense Battalion (Yonmarhanlan);

g. Mothership Unit as a unit that is specific to the base.

Lantamal VIII Manado oversees four Navy base, namely: Lanal Melonguane, Lanal Toli-Toli, Lanal Gorontalo and Lanal Bau-bau. The distance between Bitung and the four Lanals is further than the distance between Bitung and Lantamal VIII Manado. So that the most appropriate to be developed as an aircraft carrier is Lantamal VIII Manado.

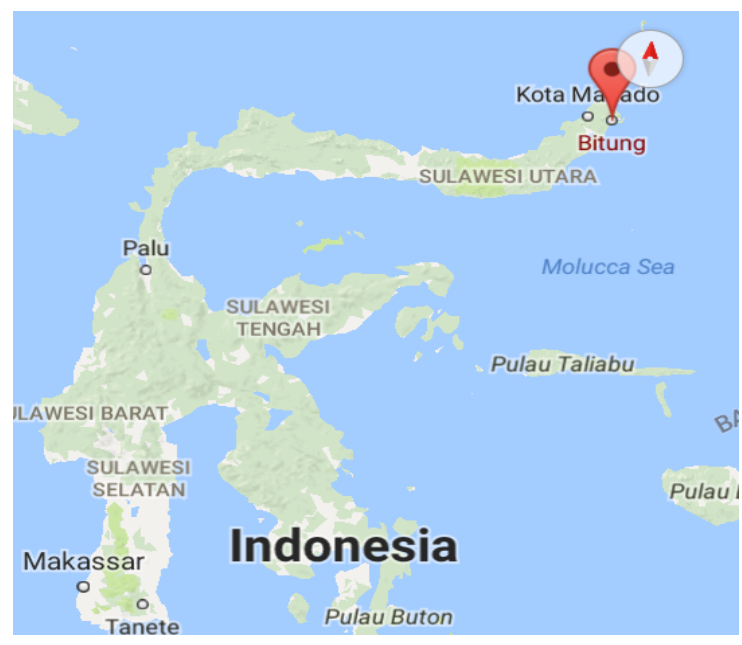

Figure 2 - Map og Bitung

This is indeed different from what was planned by the government. The selection of Lantamal VIII Manado as the mother ship took into account various factors, including the availability of facilities and infrastructure, air base facilities, availability of human resources (SDM).

In addition, Lantamal VIII Manado is already a Main Base so that the organizational structure has been formed; it only needs to be added to the Aircraft Carrier Unit as a unit that is special for its development.

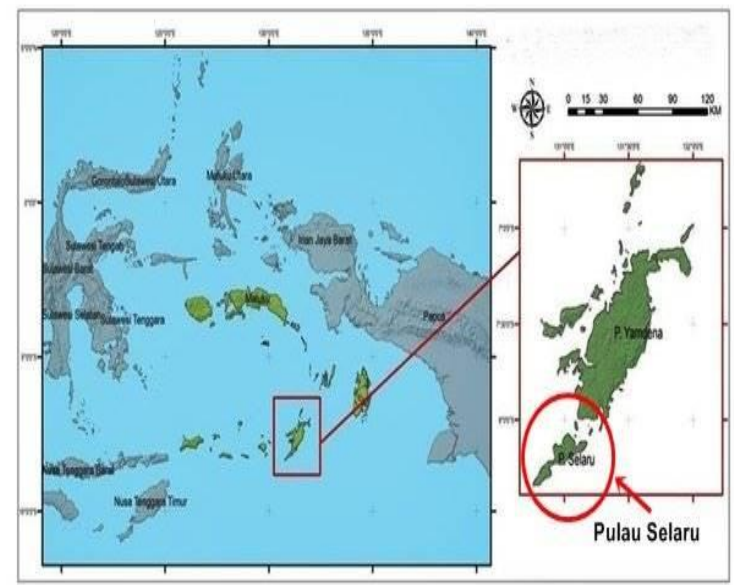

Figure 3 - Map of Salaru 
Lantamal IX Ambon oversees four Navy Base, namely: Lanal Aru, Lanal Tual, Lanal Saumlaki and Lanal Ternate. Of the four Lanals, the most appropriate to be developed is the Saumlaki Lanal, which is located in the Tanimbar Islands. Lanal Saumlaki can be developed into Lantamal so that it can carry out functions such as Lantamal VIII Manado, with the addition of an Aircraft Carrier Unit as a unit that is specific to the base.

SWOT analysis is the identification of various factors systematically to formulate an organizational strategy. SWOT analysis is based on logic in order to maximize strengths and opportunities and simultaneously minimize existing weaknesses and threats. In a strategic decision-making process, it is always related to the development of the organization's vision, mission, and policies. Therefore, strategic planning must analyze the organization's strategic factors, both the strengths and weaknesses as well as the opportunities and threats that exist today. ${ }^{21}$

The SWOT analysis method is used to determine the current strength factor of the Indonesian Navy in order to develop Indonesian Navy bases as aircraft carriers. The strength factors reviewed here consist of various aspects, namely: the availability of the Indonesian Navy base, air base facilities, facilities and infrastructure, manned human resources, weapons technology, maintenance and repair facilities. Then the strength factor is faced with weakness factors that will become obstacles, namely: limited available budget; limitations of the weapon system owned; the limited number of human resources capable of mastering the latest weapons technology. In addition, it is also to find out what opportunities the Indonesian Navy currently has in order to develop the Indonesian Navy base as an aircraft carrier. Opportunity factors that are owned are: state stability conditions that are getting better; the policy of the central government and local governments as well as high-ranking TNI/TNIAL officials to make the leading islands as aircraft carriers. Furthermore, the opportunity factor will be faced with the threat factors faced, namely: threats originating from abroad (pressure from large and powerful countries, foreign policy of neighboring countries, violation of territorial boundaries, international terrorists, smuggling of weapons and drugs, theft of wealth), sea and domestic threats (armed separatist movements and terrorists originating from within the country, smuggling of natural resources abroad and environmental destruction).

By using the SWOT analysis method, strategies and efforts that can be made by the Indonesian Navy will be generated by maximizing the strengths and opportunities it has and minimizing weaknesses and threats that will become obstacles in developing the Navy Base as an aircraft carrier.

First, Natuna is geographically located at a position of $3^{\circ}-4^{\circ} 46^{\prime}$ North and $107^{\circ} 45^{\prime}$ $108^{\circ} 23^{\prime}$ East, which is in the north close to the border areas of neighboring countries such as Malaysia, Singapore, Vietnam and Cambodia and the South China Sea. ${ }^{22}$ Likewise, Manado, which is the second largest city in Sulawesi after Makassar, is geographically located at $1^{\circ} 30^{\prime}-1^{\circ} 40^{\prime} \mathrm{N}$ and $124^{\circ} 40^{\prime}-124^{\circ} 50^{\prime} \mathrm{E} .^{23}$ located in the north close to the border area facing the Philippines. Furthermore, Saumlaki is located in the West Southeast Maluku Regency, $\pm 500 \mathrm{~km}$ to the south from Ambon City. Saumlaki is geographically located in the position of Saumlaki located at $6^{\circ}-8^{\circ} 30^{\prime} S$ and $125045^{\prime}-133^{\circ} \mathrm{E}^{24}$ Saumlaki also has a strategic position because it is located close to the border between Indonesia and Australia, to be precise from the northern part of Australia.

Second, the current state of stability is getting better from time to time, so that it can gradually increase economic growth. This also affects development in various sectors. This condition is an opportunity for the Indonesian Navy in the context of developing its own base to be used as an aircraft carrier.

Third, the policy of the central government, in this case President Joko Widodo, is to make the islands as aircraft carriers, which is supported by the Minister of Defense, the Commander of the Indonesian Armed Forces and the Chief of Staff.

Fourth, the support of the local government to upgrade Lanal Ranai to Lantamal Ranai so that security in the Natuna sea can be maintained while at the same time it aims to encourage development in Natuna so that it can be upgraded from a Regency to a Province. 
Fifth, the 1945 Constitution which states that the Government of the State of Indonesia has an obligation to protect the entire Indonesian nation and the entire homeland of Indonesia and to promote public welfare, educate the nation's life, and participate in carrying out world order based on independence, eternal peace and social justice. Law Number 3 of 2002 concerning State Defense, namely in article 1 number 5 it is stated that the main component of national defense is the Indonesian Armed Force (TNI) which is ready to be used to carry out defense tasks, ${ }^{25}$ and Law Number 34 of 2004 concerning the TNI which states that the TNI as the main component in the field of national defense, it carries out the task of upholding the sovereignty and integrity of the Unitary Republic of Indonesia. ${ }^{26}$ Article 9 states that the tasks of the Indonesian Navy include carrying out the duties of the TNI in the maritime field in the field of defense, enforcing the law and maintaining security in the marine area of national jurisdiction in accordance with the provisions of ratified national and international law, and carrying out the duties of the TNI in the development and development of military forces at sea.

Sixth, the Decree of the Minister of Defense Number: KEP/104/M/I/2020 concerning the 2020 State Defense Policy which was signed by the Minister of Defense Prabowo Subianto. ${ }^{27}$ Several important things as strategic targets for national defense are: Maintaining state sovereignty in land, sea and air areas including in border areas, Protecting the territorial integrity and safety of the Indonesian nation from all forms of threats originating from within and outside the country, Realizing a strong TNI posture In overcoming all threats, the formation of an Integrated TNI Unit (STT) for the outer islands in Natuna, Saumlaki, Morotai, Biak, and Merauke, Strengthening the marine defense area by increasing the strength of the $\mathrm{KRI}$ and increasing the capability of base facilities.

First, the biggest threat in Natuna currently comes from outside, namely the Chinese state which unilaterally claims that the South China Sea is their territory based on a map made by China, then the Natuna Islands area becomes part of China's power. The Nine Dash Lines or Nine Imaginary Lines are demaracation lines established by the Chinese government around 1949 to claim most of the South China Sea.

Second, apart from China, fishing vessels from several countries such as the Philippines, Thailand and Vietnam also frequently violate Indonesian maritime boundaries. As a result of illegal fishing, state losses per year can reach Rp 240 trillion according to calculations from the Ministry of Maritime Affairs and Fisheries. ${ }^{28}$

Third, other threats are smuggling, such as narcotics and illegal fuel transfers (illegal mining). Meanwhile, the military threat that should be watched out for is the violation of maritime, air and land boundaries. ${ }^{29}$

Fourth, the threat that occurs in the border area of North Sulawesi, namely in the work area of Lantamal VIII Manado. Manado as the capital of the province of North Sulawesi which is located directly adjacent to the Philippines. The number of transnational crimes in this region is quite large. The province also has places for the movement of people and goods on an international scale, such as Sam Ratulangi Airport in Manado and Bitung Harbor. The security forces in this area handle many cases of law violations that occur around the border and involve citizens of other countries, especially narcotics crimes and fisheries crimes.

Fifth, in this region there is also a potential vulnerability to other international crimes, such as arms trafficking, human trafficking and terrorism. ${ }^{30}$ Vulnerability to terrorism crimes as a result of the situation in the Southern Philippines. The southern Philippines is a base for militant groups led by the Abu Sayyaf. In the Balut-Sarangani islands, there are armed groups known as the Moro National Liberation Front (MNLF) and the Moro Islamic Liberation Front (MILF). The MNLF group's base is in the mountains in the hamlet of Kawayan, Barangay Kepinggan. Meanwhile, the base of the MILF group is in Barangay Balibo. Therefore, this region has become an area that is at risk of armed conflict and acts of terror for years.

The North Sulawesi Regional Police (Polda) has provided information that when riots occurred in Maluku and bombs exploded in Bali and Jakarta, a number of people suspected of being terrorist groups were known to often enter Indonesia from the Balut-Sarangani 
Islands or General Santos in the southern Philippines. ${ }^{31}$ They transited in the Talaud area, namely on Miangas Island or Marore Island, after which they continued their journey to Maluku through North Maluku Province. After several terrorist acts occurred in Java and Bali, a group of suspected people had disappeared from Sangihe and Talaud. The suspected terrorists are expected to move around by taking advantage of the facilities provided for local residents from the Southern Philippines and North Sulwesi in order to make family visits.

Sixth, Olly Dondokambey while serving as Governor of North Sulawesi reminded seafarers who crossed the seas of the Indonesia-Philippines border to be aware of piracy attacks in these territorial waters. This appeal was conveyed in connection with the piracy incident of the Abu Sayyaf group which took 12 crew members of the KM Brahma ship hostage, three of whom were crew members from North Sulawesi. ${ }^{32}$

Seventh, in Saumlaki the potential threat comes from Australia as the largest country in the south of Indonesia. Australia is one of the NATO member countries that has the support of the United States and Britain in the defense sector.

By mid-May 2015 the United States Marines in Darwin had reached 1,150 soldiers. America has drastically increased its military operations in the western and northern parts of the Australian continent, and made Darwin a major military base. This was done with the pretext of balancing China's power and as an effort to secure American interests in the region. In fact, the distance between Darwin and Indonesia's foremost island in the south, namely Selaru Island, East Nusa Tenggara is only 473 kilometers. A distance that can be reached in less than 20 minutes using the F-16 Fighting Falcon fighter. Meanwhile, the distance between Darwin and the Masela Block which contains fossil energy is only 492 kilometers. ${ }^{33}$

The Australian government has published a defense white paper entitled "Defending Australia in the Asia-Pacific Century: Force 2030". According to the Australian Minister of Defence, the Royal Australian Navy will grow into a bigger and stronger maritime power supported by its increasing capabilities. In addition to doubling the number of submarines it currently has and procuring eight frigates with anti-submarine warfare capabilities to replace the ANZAC-class warships, the Australian government is also planning to procure a new transport ship, 20 Offshore Combatant Vessels, 6 Heavy Landing Crafts and one auxiliary ship. $^{34}$

The real condition of the development of Australia's defense forces is a potential threat to the Indonesian state, which is just north of Australia. This is because many Australian interests have to pass through the territory of the Indonesian state. Several times Australia has tried to interfere with Indonesia's sovereignty, such as wiretapping. In addition, several Australian citizens were also arrested when they tried to smuggle drugs into Indonesia.

First, the strength factor that supports Natuna as an aircraft carrier is the availability of useful facilities/infrastructure to support the function of the aircraft carrier, namely the Raden Sadjad air base in Natuna. ${ }^{35}$ Air bases are indispensable as a place to take off fighter planes which are alerted as one element of the strength of the aircraft carrier.

Second, the strength factor possessed by Lantamal VIII Manado to be developed into an aircraft carrier is very large. This is because Lantamal VIII Manado already has more complete facilities and infrastructure because of its status as the Main Base. The development of Lantamal VIII Manado takes into account that Manado has Sam Ratulangi International Airport which is about $37 \mathrm{~km}$ from Bitung City using the Manado-Bitung main road, if it is reached by car it takes about 1.5 hours. In addition, there are also Bitung Harbor Pier, namely: Ocean Pier (607 m long); Nusantara Pier (length $504 \mathrm{~m}$ ); Basic Chemical Industry Pier/IKD (148 m long); Landing Craft Tank/LCT Wharf (20 m long) and Local Pier (60 m long). ${ }^{36}$

Third, the strength factor that supports Saumlaki as an aircraft carrier is the availability of useful facilities/infrastructure to support the function of the aircraft carrier, namely Mathilda Batlayeri Airport. The location of the airport is on Jalan Mangkawar, Lorulun. Andara has a runway length of $1641 \mathrm{~m} 2 \times 30 \mathrm{~m} 2 .^{37}$ This airport can be used as a takeoff place for fighter planes that are alerted as one element of the strength of the aircraft carrier. 
Fourth, the human resources available to become carrier crew members of the aircraft carrier come from Indonesian Navy personnel who are experienced in carrying out tasks on the Indonesian Warships (KRI). Human resources is an important factor because the equipment used by aircraft carriers is equipment with sophisticated technology, both sensor/detection equipment, communications and weapons used for defense and destroying the enemy. The carrier's armament consists of cannons, rockets and missiles that have effective destruction power, long range, precise accuracy and high speed. In addition, it is also equipped with equipment that has the ability to carry out electronic warfare. ${ }^{38}$

First, the current state of the Alutsista owned by the Indonesian Navy is not comparable to the area of the task field and the potential threats that exist. The Minimum Standards of Essential Force (MEF) are still an obstacle in the implementation of the tasks carried out. This is due to the technical condition of the Alutsista which needs to carry out repairs and maintenance. So that not all KRls, planes, tanks and other combat equipment can support the security of Indonesian vast territory.

Second, the budget available to support defense is still not sufficient to buy armaments which are expensive. The budget used so far comes from the central government. This budget constraint can be overcome by developing the base so that it can function as an aircraft carrier. However, budget constraints can also have implications for the limited capabilities of the weapons systems owned and the ability to master the latest weapons technology.

From the explanation above, it can be grouped the factors that become opportunities, threats, strengths and weaknesses as follows:

a. Opportunity factors include:

- Strategic position located close to the border area;

- The current state of stability is getting better;

- Supporting central and local government policies;

- Support from high-ranking TNI and Navy officials;

- The mandate of the 1945 Constitution, Law Number 3 of 2002 concerning State Defense and Law Number 34 of 2004 concerning the TNI;

- Decree of the Minister of Defense Number: KEP/104/M/I/2020 concerning the 2020 State Defense Policy.

b. Threat factors include:

- Breach of territorial boundaries committed by foreign countries;

- Theft of natural resources in the Indonesian seas;

- Smuggling of people, fuel, weapons, drugs and other prohibited items;

- Piracy and piracy;

- Sabotage, wiretapping and terrorism.

c. Strength factors include:

- There is a Navy base at the Lantamal and Lanal level;

- The existence of an airport that can function as an air base;

- The existence of port facilities for ships;

- Have human resources that can be prepared to become crew members of the aircraft carrier;

- Can be supported by weapons that use advanced technology.

d. Weakness factors include:

- The current Alutsista condition is not comparable to the existing task field and potential threats;

- The budget available for the Navy is still limited;

- Dependence on the budget from the central government;

- Limited capability of the weapon system owned;

- The number of human resources who master the latest weapons technology is still limited.

After analyzing external and internal factors, the next step is to determine the strategy used by integrating external strategic factors (External Strategic Factor Analysis 
Summary/EFAS) and internal strategic factors (Internal Strategic Factor Analysis Summary/IFAS) as follows:

a. SO Strategy:

- Develop a Navy base as an aircraft carrier with the support of the central government and local governments as well as high-ranking of Indonesian armed force/Navy officials;

- Realizing the national defense policy and the mandate of the law to improve national defense in order to safeguard the territory and sovereignty of the Unitary State of the Republic of Indonesia.

b. WO Strategy:

- Develop the Navy base in stages with a priority scale and adjusted to the available budget from the government;

- Planning to increase budget requirements, in order to realize government policies and mandates of the law.

c. ST Strategy:

- Develop the Navy base as an aircraft carrier in the context of dealing with violations of the sovereignty of the Indonesian state;

- Improving the capability of the Navy bases to tackle criminal acts in the Indonesian seas.

d. WT Strategy:

- Develop Navy bases in stages to deal with potential threats;

- Make a plan to increase budget requirements, to overcome criminal acts in Indonesia's marine areas.

\section{CONCLUSION}

The strategic geographical constellation of Indonesia as a sea line of communication (SLOC) and sea line of trade (SLOT) for the international community is very profitable and can also pose a threat to state sovereignty. Faced with the dynamics of the development of the strategic environment, both nationally, regionally and globally, currently, Indonesia has demanded to strengthen the national defense system. However, with the limited budget available, an appropriate strategy is needed in order to increase state defense. Based on the government's policy to build aircraft carriers by utilizing islands in the border area, a strategy for developing a Navy's base is needed using the SWOT Analysis method. By integrating EFAS and IFAS, the best strategy is the SO strategy, which is to develop the Navy Base as an aircraft carrier by utilizing support from the central government and local governments as well as high-ranking of Indonesian armed force/Navy officials so that state defense policies and the mandate of the law can be realized to improve national defense in order to protect the territory and sovereignty of the Unitary State of the Republic of Indonesia.

In its implementation so that the development of the Navy Base as an aircraft carrier can be carried out properly, a further study is needed at the leadership level of the Navy, Armed force, and government as well as related officials, so that it can be adapted to the needs and developments of the strategic environment, both at the national and regional levels, as well as globally. This is intended so that the development of the Indonesian Navy base as an aircraft carrier has a long-term continuity value for the future.

\section{REFERENCES}

1. I Nengah Putra, Analisis Ancaman Maritim Sebagai Dampak Perkembangan Lingkungan Strategis (Surabaya: Bintang, 2016), hlm.3.

2. Mabesal, "Keputusan Kasal Nomor Kep /06/II/2001 Tentang Penataan Gelar Dan Klasifikasi Pangkalan-Pangkalan TNI Angkatan Laut" (Jakarta, 2001).

3. "https://www.bing.com/search?q=dari+17.504+pulau+di+indonesia\%2c+16.056+telah+div erifikasi+pbb+\%7c+merdeka.com\&cvid=b5399429ebfe4f4f992ea918c316887d\&aqs=edg 
e..69i57.1468j0j1\&pglt=43\&form=annta1\&pc=asts," Diakses Selasa, 4 Mei 2021, Pkl. 09.58 WIB.

4. Supartono, Empowerment Management of Outermost Small Islands in Improving National Defense and Security, Edition 1 (Depok: PT Rajawali Buana Pustaka, 2020), page.2.

5. Aan Kurnia, Between Threats and Opportunities (Jakarta: Epicentrum Walk, 2017), page.13.

6. Till Geoffrey, Seapower - A Giude for The Twenty First Century, Edisi 2 (London, 2009), page.345.

7. Kurnia, Between Threats and Opportunities, page.14.

8. 1945 Constitution of the Republic of Indonesia.

9. Muhammad Zulkifli, "Determining The First Priority Of The First Arsenal Location To Support The Operation Of The Indonesian Warship In Safety Of The East Indonesian Sea Region With Ahp Methods," International Journal of ASRO, Number 2, pp.42-53, Volume 10 (2019).

10. "Perpres No. 16 of 2017 concerning Indonesian Marine Policy," 2017.

11. "https://katadata.co.id/berita/2017/12/14/tiga-pulau-disulap-jadi-kapal-induk-tni-bakalberoperasi-2019," Accessed Thursday 1 April 2021, Pkl. 13.28 WIB.

12. "https://nasional.republika.co.id/berita/o841zj365/pulaupulau-strategis-bakal-difungsikansebagai-kapal-induk," Accessed Thursday, April 1, 2021, Pkl. 13.28 WIB.

13. "Https://Katadata.Co.Id/Berita/2017/12/14/Tiga-Pulau-Disulap-Jadi-Kapal-Induk-TniBakal-Beroperasi-2019," Accessed Thursday, April 1, 2021, Pkl. 13.28 WIB..

14. Ministry of National Education, Big Indonesian Language Dictionary, Language Center, Edition 4 (Jakarta: PT. Gramedia Pustaka Utama, 2008).

15. Freddy Rangkuti, Analisis SWOT Business Case Dissecting Techniques (Jakarta: PT. Gramedia Pustaka Utama, 2008), page.4.

16. "Decree of the Minister of Defense Number: Kep / 104 / M / I / 2020 concerning State Defense Policy in 2020" (Menteri Pertahanan, 2020), page.2.

17. Ibid., page.4.

18. "Map of the Indonesian Fleet Command's Working Area I, II Dan III" (Puskodal TNI AL, 2018).

19. Joko Purnomo, "The Model for Determining Location of Naval Base Using Ahp Method and Set Covering Problem," RJOAS, 2020, https://doi.org/DOI 10.18551/rjoas.202005.13 .

20. "Natuna Island Map - Google Search" (accessed Monday, 19 April 2021, at 02.14 WIB).

21. Commander of Lantamal V, Organization and Procedures of Lantamal V Surabaya (Lantamal V, 2015).

22. "https://knkword.wordpress.com/2017/10/13/kota-bitung-sulawesi-utara-tempat-wisata/" (diakses Minggu, 19 April 2021, pkl. 01.50 WIB).

23. "Selaru Island Map - Google Search" (accessed Sunday, 19 April 2021, 02.04 WIB).

24. Rangkuti, Analisis SWOT Business Case Dissecting Techniques, page.18.

25. "https://travel.detik.com/detiktravel/d-5123101/kondisi-geografis-pulau-natunaberdasarkan-peta-lengkap-dengan-iklimnya," Accessed Tuesday, April 20, 2021, at 02.21 WIB, n.d.

26. "https://dpmptsp.natunakab.go.id/profil-kabupaten-natuna/\#: :text=secara\%20geografis \%2c\%20wilayah\%20kabupaten\%20natuna,selatan\%20berbatasan\%20dengan\%20kabup aten\%20bintan\%2c," Accessed Tuesday, April 20, 2021, at 01.44 WIB.

27. Lukman Yudho Prakoso, "Defense Strategy in Handling Transnational Crime at the Manado Sea Border, North Sulawesi in 2017," 2017, page.1.

28. Karel Fredrik Gaus Basar Lusnarnera, "Formulation of Strategic Plan for Management of Saumlaki Airport, West Southeast Maluku Period 2014 - 2018," Universitas Atma Jaya, 2014.

29. "Law Number 3 of 2002 concerning National Defense" (Lembaran Negara Republik Indonesia Tahun 2002 Nomor 3). 
30. "Law Number 34 of 2004 concerning the Indonesian Armed Force." (Lembaran Negara Republik Indonesia Tahun 2004 Nomor 127).

31. "Keputusan Menteri Pertahanan Nomor: Kep / 104 / M / I / 2020 Tentang Kebijakan Pertahanan Negara Tahun 2020."

32. Kurnia, Between Threats and Opportunities, page 6.

33. Ibid., page 27.

34. Prakoso, "Defense Strategy in Handling Transnational Crime at the Manado Sea Border, North Sulawesi in 2017."

35. Ibid.

36. "https://www.beritasatu.com/nasional/357581/perlu-kewaspadaan-di-laut-perbatasanfilipina-manado," Accessed Wednesday, May 5, 2021, Pkl. 11.44 WIB.

37. Gatot Nurmantyo, Struggle and work together to make Indonesia a winning nation (Jakarta: Mabes TNI, 2016).

38. Marsetyo, "The Navy's Strategy in Securing the Maritime Boundary of the Republic of Indonesia," Universitas Diponegoro Volume 17.

39. "https://www.bing.com/search?q=peresmian+perubahan+nama+lanud+ranai+menjadi+la nud+raden+sadjad+(tniau. mil.id)\&cvid=5c37d2ab3f3d436982468aaf4d2fad85\&aqs=edge..69i57.1799j0j4\&form= anab01\&pc=asts," Accessed Thursday, May 6, 2021, at 19.17 WIB.

40. "http://pidii.info/index.php?option=com_k2\&view=itemlist\&layout=category\&task=category \&id=139\&itemid=221," Accessed Wednesday, May 5, 2020, Pkl. 11.42 WIB.

41. "http://www.mtbkab.go.id/bandar-udara," Accessed Friday, May 21, 2021, Pkl. 11.56 WIB.

42. Mabesal, Manual for the Implementation of the Indonesian Navy's Electronic Warfare Implementation (Jakarta, 2014), page.5. 